\title{
The Field Observed Insects would Challenge The Expansion of Porang (Amorphophallus Muellery Blume) Cultivation in Indonesia
}

\author{
Muchdar Soedarjo* \\ Indonesian Legume and Tuber Crops Research Institute, P.O. Box 66, Malang, Indonesia 65101
}

*Corresponding Authors: Muchdar Soedarjo, Indonesian Legume and Tuber Crops Research Institute, Malang, Indonesia

Abstract: Porang (Amorphophallus muelleri Blume) has becomed an important agribusiness crop in Indonesia in the past recent years. Porang in the form of chips and flour has been exported to some countries. The processed products of porang have been proven to be useful for mantaining human health and for alleviating some illness. Consequently, corm of porang has been marketted at higher price than other tubers. The government of Indonesia also promoted the expansion of porang cultivation. As a result, growing porang on open agricultural land is unavoidable. The crops, like rice and maize, which have been commonly cultivated on large and open areas in Indonesia, experienced a serious damaged and even a failure of harvest by insects and diseases. Similarly, porang plants would possibly be exposed to a serious infestation of insects and pests when cultivated on open and larger areas. On the basis of the present field observation, some insects, listed in the following sections, were found on porang. These insects could potentially challenge the cultivation of porang in Indonesia in the future.

Keywords: Porang (Amorphophallus muelleri Blume), farming, insects

\section{INTRODUCTION}

Sweet potato and cassava are tuber crops and ones of the important food sources for the people of Indonesia (Zuraida and Supriati, 2001; Saleh and Widodo, 2007; Hardoko et al., 2010; Ginting et al., 2014). Unlike sweet potato and cassava, porang (Amorphophallus muelleri Blume) has been considered as under-utilized tuber crop in Indonesia. However, due to its value in maintaning human health and curing some human illness (Yoshida et al., 2006; Yeh et al., 2007; Carlos et al., 2008; Alonso-Sande et al., 2009; Jagatheesh et al., 2010; Soedarjo, 2015), porang plant is becoming one of the important commercial tuber crops. As observed in farmers field in 2019-2020, the price of porang fresh tuber was much higher compared to the price of sweet potanto and cassava fresh tubers. Consequently, more farmers would be growing porang and larger area of porang cultivation is unavoidable.

As a commercial crop, porang in the form of chips and flour has been exported to Japan, China, and Korea and Australia at the present (Abriyani, 2019; Ahmad, 2019; Gesha, 2019 and Handayani, 2019). In support to porang cultivation enlargement, the Indonesian Ministry of Agriculture has introduced a program to increase corm production of porang (Sugara, 2020). Porang plant has been 
naturally cultivated in forest under some degree of shading by the trees. Porang plant was reported to grow normally on Alfisol soil whothout shading (Soedarjo et al., 2020). Therefore, the expansion of porang cultivation could be carried out on open-farming areas. Expectedly, a significant corm production woud be achieved to meet the export demand.

However, farming of porang on open areas would be challenged by pest and diseases infestation. Sweet potato, cassava and other crops cultivated in a larger area on open areas have been deleteriously damaged by pests and diseases damages. Growth, yield and economic reduction due to pests and diseases infestation have been well-documented (Saleh et al. 2015; Marwoto et al. 2017; Faizin et al. 2019). Thus, taking porang to open-farming areas could similarly undergo damages and economic loss due to pests and diseases infestation. On the basis of field observation results, this manuscript reported the first information about the presence of some insects and the resulted damages on porang plants grown in the glasshouse and on farmers field.

\section{MethodologY}

The present observation monitored the presence of insects on porang (Amorphophallus muelleri Blume) at farmers field, Probolinggo-East Java, and on porang plants at the Campus of Indonesian Legumes and Tuber crops Research Institute (ILeTRI), Malang-East Java. The field visit and field observation were undertaken during the porang growing season, from December 2019 to April 2020. The damage symptoms due to the respected insects was photographed as a proof of the insect infestation. Whenever possible, the yield reduction of porang due to the damage by certain insect was recorded quantitatively. The insects observed on porang plants were consulted to the entomologist in ILeTRI to identify the names of the insects. The names of insects found on porang plants were reported as listed in the following sections.

\section{RESULTS AND DisCUSSION}

\subsection{Warehouse moth (Ephestia cautella)}

Ephestia cautella is a tropical warehouse moth and is allso called as an almond moth or cocoa moth. The larvae, puppae and imago of the moth are presented in figures $1 \mathrm{~B}, 1 \mathrm{C}$ and $1 \mathrm{D}$, respectively. The larvae of this warehouse insect was reported to cause an economic loss to the various stored products, such as dates, cacao, shallots (Aldawood 2013; Hasyim et al., 2014; Oyewo and Amo, 2018). The mean percentage of damage to cocoa beans by E. Cautella were 10.31 and 29.05 in the first and fourth months, respectively (Oyewo and Amo, 2018). Thus, the seeds stored longer would result in worse damages.
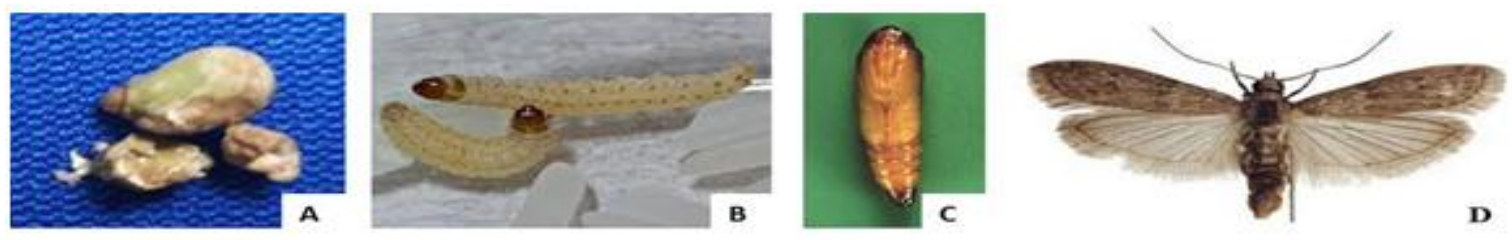

Figure1. A. The damages of porang seeds by Ephestia cautella (present observation), B. Larvae of warehouse moth, C. Puppae of warehouse moth and D. Imago of warehouse moth.

$B, \quad C$ and D: (http://www.russellipm-storedproductsinsects.com/portfolio/anthrenus-verbasci-varied-carpetbeetle-2/- (accessed in 7 Nopember 2019:). 
The present observation showed that the insect also attacked the seed of porang (Amorphophallus muelleri Blume) stored uncealed at room temperature. The larvae of moth damaged the seeds of porang by feeding. As a result, porang seeds were seriously damaged and the apperance of damaged porang seed was presented on figure $1 \mathrm{~A}$. Initially, the moth attacked soybean seed stored side by side to the seed of porang. After a serious damage of soybean seeds, the larvae of moth also damaged the seed of porang. The result of this observation suggests that the moth Ephestia cautella preferred seeds of soybean to the seeds of porang. The present observation revealed the first information that the warehouse moth Ephestia cautella also attacked the stored seed of porang.

\subsection{Mealybug}

Mealybugs are insects that live on a wide range of host plants and are considered to be highly polyphagus (Addis et al., 2008; Mani et al., 2012; Sirisena et al. 2013). Mealybugs damage the host plants by inserting their hair-like mouthparts into plant tissue to suck up the sap of plant cell. An infestation of this insect was reported to deleteriously affect the growth and yield of host plants, e.g., enset plant (Addis et al., 2008). Warm dry weather, prolonged drought with scanty rain fall and less number of rainy days favour the faster multiplication of mealybugs (Ayyasamy and Regupahy, 2010). As a tropical country, Indonesia should be a favourable place for the mealybugs to properously grow. Thus, porang plants which is native to Indonesia could be a host to mealybugs.

Our observation revealed that porang plants planted on farmers' field and in the glasshouse were not infested by mealybugs. However, bulbils of porang stored at room temperature were infested by mealybugs. Bulbils infested by mealybugs were indicated by white color coverage on the surface of bulbils (Fig. 2 left). Whilst, clean surface of bulbil was shown by the uninfested one (Fig. 2 right). The diameter of bulbils on figure 2 (left and right) was measured to be approximately $3.0 \mathrm{~cm}$. The weight of bulbils on figure 2 left and 2 right were 9.71 and $9.83 \mathrm{~g}$. Thus, an infestation by mealybug caused a slight decrease of bulbil weight. Mealybugs live by sucking up the sap of the cell (Addis et al., 2008). The sap-sucking up of bulbil by malybugs could be the mechanism for a slight reduction of bulbil weight.
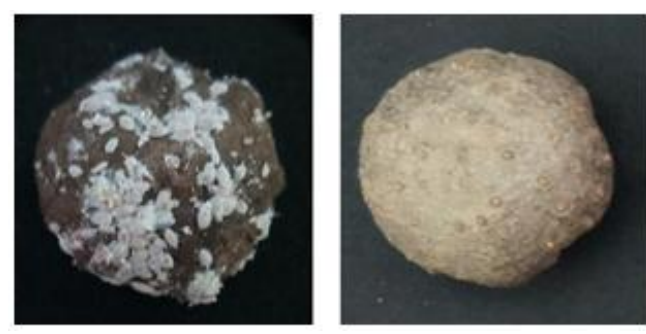

Figure2. Mealybug-infected bulbil (left)nd healthy bulbil (right)

\subsection{Hornworm (Agrius convolvuli)}

Hornworm (Agrius convolvuli) is considered to be polyphagous insect, because it could feed on most leaves of the various plants (Kaya et al., 2016; Halder et al. 2018). As observed on sweet potato, the larvae of Agrius convolvuli seriously damaged the leaves and caused in significant reduction in tuber yield (Figs. 3 A, B, C and D) (Halder et al., 2018). 

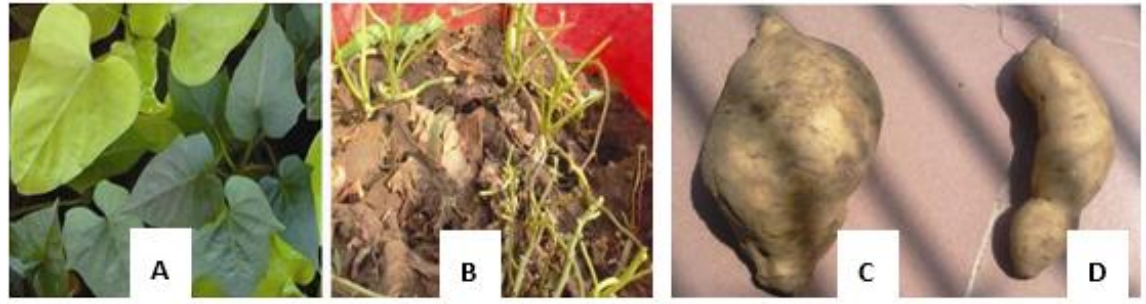

Figure3. Performance of healthy sweet potato (A), growth of infested sweet potato by larvae of Agrius convolvuli (B), tuber of non-infested $(C)$ and tuber of infested sweet potato by larvae of Agrius convolvuli (D).

The larvae of Agrius convolvuli also damaged tuberous porang plant by feeding the leaves (Figure 4A and $4 \mathrm{~B}$ ). All parts of the leaves, including the midrib of the leaves, were also eaten (Fig $4 \mathrm{~B}$ ). However, the larvae of Agrius convolvuli did not fed on the leaves of the climbing ornamental plant which has similar form of leaf with taro plant (Fig. 4 C). Thus, the leaves of this ornamnetal plant were not preferred. The present observation revealed the first report regarding the preference of the larvae of Agrius convolvuli feeding on porang leaves. Referring to the damage of sweet potanto (Halder et al., 2018), the larvae of Agrius convolvuli could be a potential insect that could significantly reduce growth and corm yield of porang.
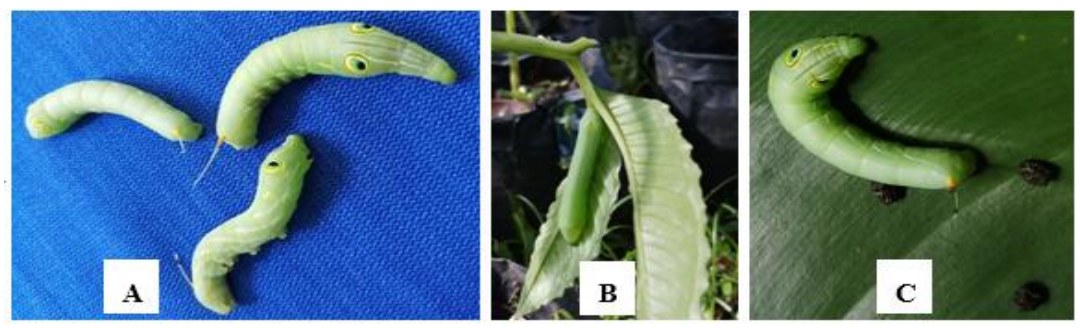

Figure4. Larvae of Agrius convolvuli found on porang leaves (A), the larvae feeding on leaves of porang plant $(B)$ and and the appearance of larvae of Agrius convolvuli fed by the leaf of ornamental crop $(C)$

\subsection{Armyworm (Spodoptera litura)}

Armyworm, Spodoptera litura, is a polyphagous insect and could damage variety of crops, fruits and vegetables (Tengkano and Suharsono. 2005; Oliveira et al., 2014; Rebek and Hillock 2015; Igyuve et al., 2018; Lolodatu et al., 2019). The appearance of larvae, imago of armyworm and porang leaf damaged by the armyworm were depicted on figure $5 \mathrm{~A}$ (https://nufarm.com/id/gabah-2/ulat-grayak/), figure 5B (https://www.google.com/search? source=univ\&tbm=isch\&q=image+ulat+ grayak\&client $=$ firefox-b-d\&sa $=X \& v e d=2$ ahUKEwi5yK3V0NdqAhX-ILcAHVG2DI8Q7A16BAgKECY\&biw=126 $6 \&$ bih $=674 \#$ imgrc $=7$ t1Ls-NfWHk fSM) and $5 \mathrm{C}$ (present observation) respectively. The larvae of armyworm preferably damages leaves of plant by feeding. Recently, it was reported that armyworm badly attacked thousands of hectars of agricultural crops in Nusa Tenggara Timur, Indonesia and resulted in significant economic loss (Rosary, 2020). The present observation also revealed that porang leaf was prefered for feeding by armyworm and was badly damaged. Therefore, the porang leaves were also deleteriously damaged (Fig. 5 C). Thus, the present observation revealed the first information about the feeding preference of armyworm on porang leaves. 

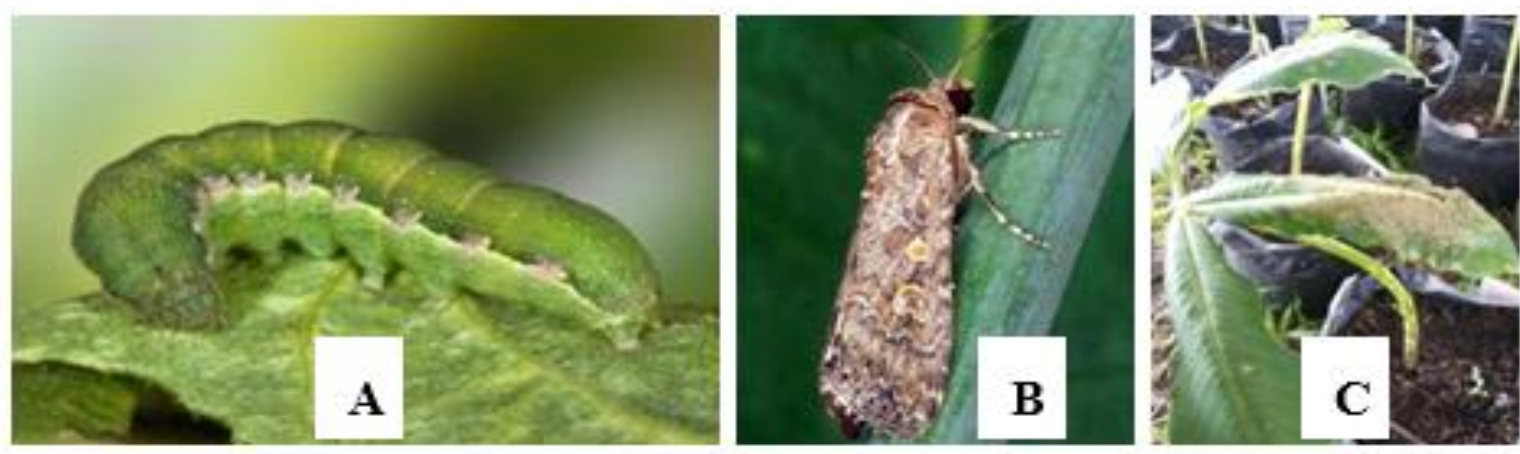

Figure5. A. Larvae of spodoptera litura (A), imago of spodoptera litura (B) and and damage of porang leaves by spodoptera litura $(C)$.

\subsection{Whitefly (Bemisia tabaci Genn)}

Whitefly, Bemisia tabaci Genn, is commonly observed to infest legumes, such as soybean, mungbean, peanut and was reported to adversely affect the growth and grain yield (Gulluoglu et al., 2010; Marwoto and Inayati. 2011; Mir Kabir et al. 2014; Kasno et al., 2015; Murgianto and Hidayat, 2017; Nurrohman et al. 2019). Beside legumes, this insect also adversely infest other agricultural crops, such as chili pepper, cassava, sweet potato , tomato, eggplant and cucumber (Narendra et al. 2017; Purnama et al. 2017; Lu et al. 2019; Mohammadali et al., 2019; Misaka et al., 2020). The adverse effect of whitefly infestation was due to its role in transmitting viral disease from infected plant to the infested plant (Narendra et al. 2017).

In the present observation, porang plants were laid out side by side to the soybean plants in the glasshouse of ILeTRI. Initially, soybean plants were seriously infested with whiteflies and the soybean leaves showed curly and dwarf. At this present observation, porang plants were not yet infested with whiteflies. The whiteflies infested porang plants after the harvest of all soybean plants. Porang plants were eventually infested with high population whiteflies. At the beginning, when population of whiteflies was low, the leaves of porang did appear curly (Fig. 6A). After sometimes, when more number of whiteflies accumulated on the below side of the leaves, the leaves of porang turned to curly (Fig 6B). Whilst, the unifested porang plants showed normal growth (Fig. 6C). The result of the present observation revealed the first information that porang plant could be infested severely by whiteflies. After harvest, the corm produced by the whiteflies infested porang was much lower (24 $\mathrm{g}$ of corm/plant) than the healthy porang plants (190 $\mathrm{g}$ of corm/plant. Corm yield was reduced by $87 \%$ due to whiteflies infestation (Fig. 6D). 

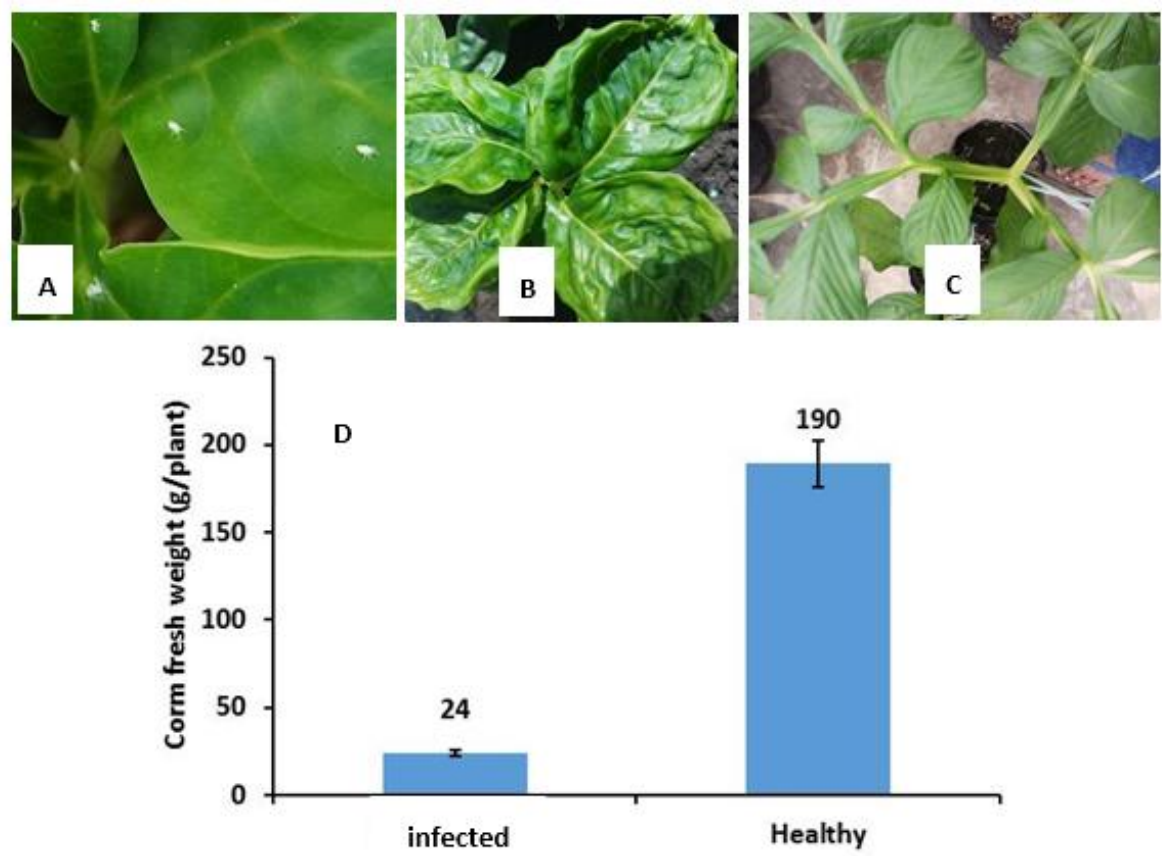

Figure6. Whiteflies on leaf of porang (A), Curly leaves of porang due to whiteflies (B), healthy porang leaves (C) and corm fresh weight of Bemisia infected and healthy porang plants $(D)$.

\subsection{Grass hopper}

The attack of grass hopper on leaves of porang was observed on porang grown in the glasshouse. The grass hopper was small, aprroximately $1 \mathrm{~cm}$ of length (head to ovipositor) (Figure 7A). The grass hopper fed on leaves and left holes after feeding (Fig. 7B). By observing the degree of leaf damages, this grasshopper does not seem to be a serious threat to growth and corm yield of porang. However, if the grass hoppers present at huge number, the damage would be possibly deleterious. The presence of certain number of grasshoppers in one plant significantly reduced the growth of wheat and canola and also teak (Begna and Fielding. 2003; Pratiwi et al., 2012). Growth reduction due to grasshoppers infestation was also reported on maize (Leatemia and Rumthe. 2011). Referring to the reports of plant damages by the previous investigators (Begna and Fielding. 2003; Leatemia and Rumthe. 2011), grasshoppers could also possibly imposed the growth damages and an economic loss to porang plant. The occurance of grasshopper on porang was the first observation reported by this present observation.
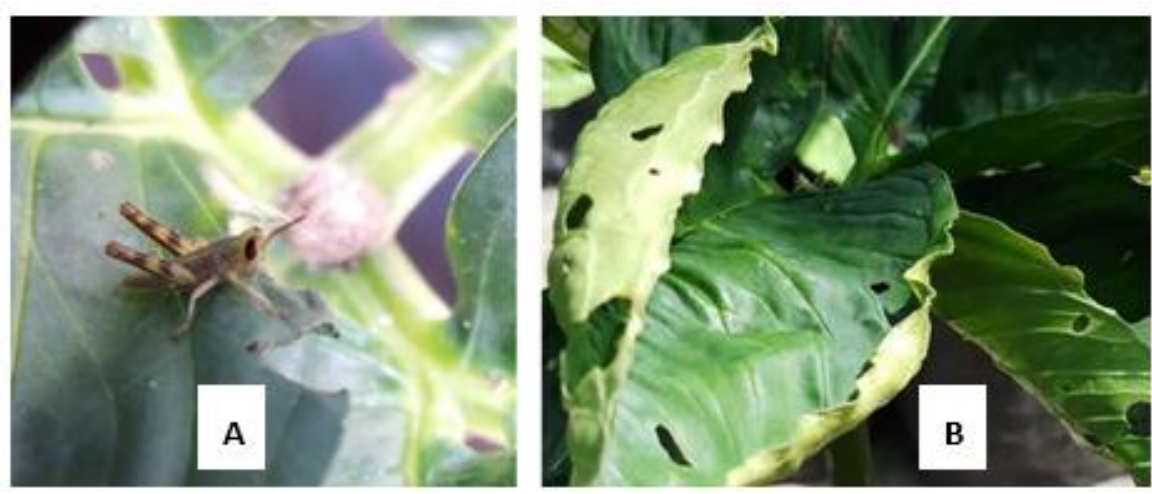

Figure7. A. Grass hopper was feeding on leaf of porang, B) the feeding left holes on leaf of porang. 


\subsection{White Grubs}

White grubs, also known as root grubs, are soil-inhabiting polyphagous insects. In soils, the larvae of white grubs utilize organic matter as well as the roots of many economic crops as their food, such as sugarcane, cassava, sweet potato, grasses and maize in all over the world (Hann et al., 2008; Mane and Mohite, 2014; Setiawati et al., 2014; Teshita and Gashaw, 2014; Adrian et al. 2019). White grubs can be devastating agricultural pests by feeding on crop roots and often resulted in plant death. This insect was reported to deleteriously attack maize in Tuban and caused around Rp 3 million loss in one hectar (Pioneer, 2018). A devastating effect of white grubs on rice plantation and sugarcane plantation was also observed and reported by Adrian et al. (2019) and Asmara (2019) in Indonesia.

The present observation revealed the ocurance of white grubs in soil planted with porang (Amorphophallus muelleri Blume) within the stand of trees in Probolinggo regency, East Java. At time of observation, the damages on porang plant was not discovered even though the white grubs were found (Figs. 8A and B). Porang was a new plant in this tree area, it was the second year of growing season. Unnoticed damages on porang plants might be due to small population of white grubs. Previously, the white grubs were not observed within the roots of the trees. Thus, the introduction of porang as new plant might induce the occurance of white grubs. Therefore, the population of white grubs would be magnifying along with the longer growing season of porang plants. As reported by previous invetigators on other crops (Hann et al., 2008; Mane and Mohite, 2014; Setiawati et al., 2014; Teshita and Gashaw, 2014; Adrian et al. 2019), the white gurbs would also impose a devastating effect on porang in the future.
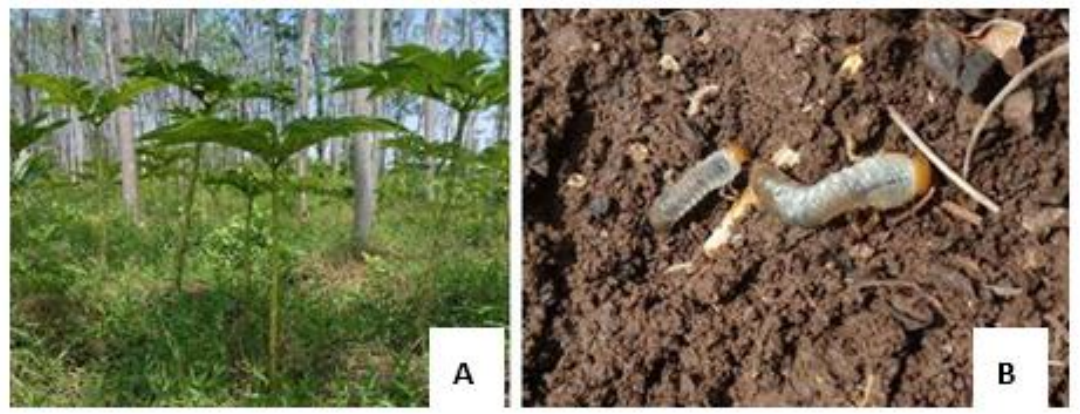

Figure8. A. Porang plants within the stand of trees and B. White grub in the soil

\subsection{Teak insect}

Porang plants was grown at farmers' field where teak tree was grown as border. Teak trees were sometime devastated by the attack of some insects. Rahmana (2016) reported a devastating infestation of larval teak insects in Pamekasan, East Java, Indonesia. The damaged-teak tree left leaves as shown in figure 9A. Similar symptom of leaf damage was also observed on leaves of teak tree in Probolinggo grown as border where porang plants were grown (Fig. 9B). Porang plants grown on farmers field in Probolinggo which was bordered with teak trees were also found to show similar damage symptom (Fig. 9C). At the time of field observation, the larvae or imago of insects infested teak tree and porang plants was not found. By comparing the damage symptom among the plants shown on Figures 9A, B and C, the type of insect was presumably the same. The insects of teak tree grown as the border would easily move to the porang plants in the field as the main crop. 


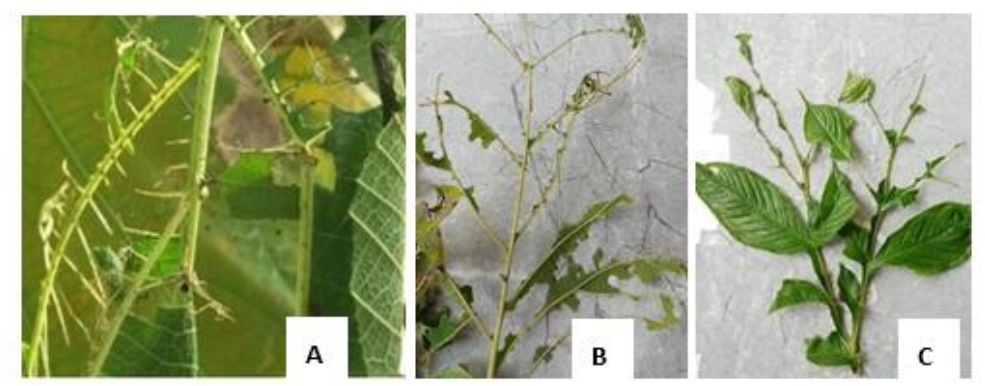

Figure 9. Symptom of damage on teak leaves due to the larvae of teak insect in Pamekasan [(A) Rahmana (2016)], symptom of damage on teak leaves in Probolinggo (B) and symptom of damage on porang leaves in Probolinggo.

\subsection{Black cutworm (Agrotis ipsilon)}

Agrotis ipsilon, black cutworm, (Lepidoptera: Noctuidae) is known to be polyphagous insect because the insect was found to attack estate plant like coffee (Coffea arabica) and cotton, vegetables and ornamental crop (Foster and Gaylor. 1987; Maghfiroh and Binawati 2012; Fernandes et al., 2013; Mamahit and Manueke. 2016; Armi et al. 2019). In Brazil, the black cutworm caused coffea plant dead of $13.9 \%$ (Fernandes et al., 2013) and serious damage of red onion, more than $50 \%$ of plant dead, was reported by Armi et al. (2019). Thus, black cutworm is considered to be one of the harmful insects.

The present work observed the occurance of black cutworm on farmers' field grown with porang. One of the porang plants grown in the glass house was found dead. When up-rooted, damaged corm of the dead porang plant was observed (Fig. 10). Near the corm was found the larvae of black cutworm. Thus, the corm could probably be fed by the black cutworm. However, the present observation did not notice the serious damage of porang plant due to black cutworm on farmers' field. Since the porang plant was newly introduced, it was the second year of porang growing season, the population of black cutworm would be too low to cause a damage to newly introduced porang plants. Referring to an adverse effect of black cutworm to plants that has been established for years, like red onion, the black cutworm could be a serious threat to porang plant in the near future.

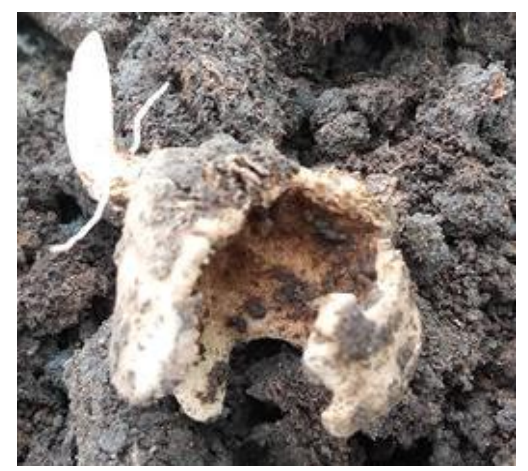

Figure 10. Damaged of corm of porang could be due to black cutworm.

\section{CONClusion}

The present work observed some insects which could be a potential threat to an expansion of porang cultivation in Indonesia. The idenfied insects in the present work are warehouse moth (Ephestia 
cautella), mealybugs, hornworm (Agrius convolvuli), armyworm (Spodoptera litura), whitefly (Bemisia tabaci Genn), grass hopper, white Grubs, teak insect, and black cutworm (Agrotis ipsilon)

\section{ACKNOLEDGEMENTS}

Part of the present observation was undertaken in the glass house of Indonesian Legume and Tuber Crops Research Institute (ILeTRI), the Indonesian Ministry of Agriculture. The author would like to thank Miss Farah Ika Ulimah, undergraduate student of the State Islamic University (UIN) - MalangEast Java, for her assistance in part of this work. I would like to thank Dr. Yadi Baliadi, Dr. Yusmani, and Mrs. Sri Wahyuni Indiati for meaningful discussion in identifying the names of the insects.

\section{REFERENCES}

[1] Abriyani A. 2019. Tepung porang di Karangtengah tembus pasar luar negeri (Porang flour at Karangtengah goes to International market) https://www.solopos.com/ tepung-porang-di-karangtengahtembus-pasar-luar-negeri-203757 (Accessed 10-10-19).

[2] Addis T., F. Azerefegne and G. Blomme. 2008. Density and distribution of enset root mealybugs on enset. African Crop Science Journal 16: 67-74.

[3] Ayyasamy R, A. Regupathy A. 2010. Need and scope for insecticide resistance management for the invasive papaya mealy bug Paracoccus marginatus Williams and Granara de Willink in small scale papaya farming system in Tamil Nadu, India. Res Pest Mgmt Newslet.19: 23-28.

[4] Adrian R., Nasamsir, dan A. Meilin A. 2019. Survei serangan hama pada perkebunan tebu (Saccharum officinarum L.) di Provinsi Jambi (Survey on insect of sugarcane plantation in the province of Jambi). J. Media Pertanian 4: 1-7.

[5] Ahmad F. 2019. Ekspor ke China dan Jepang-petani NU sukses budidaya tanaman porang (Export to China and Japan-NU farmer successfully cultivate porang). https://www.nu.or.id/post/read/111187 lekspor-ke-china-dan-jepang--petani-nu-sukses-budidaya-tanaman-porang (Accessed 10-10-19).

[6] Aldawood A.A. 2013. Effect of covering dates fruit bunches on ephestia cautella walker (lepidoptera: pyralidae) infestation: population dynamics studies in the field. Int. J. Agric. Appl. Sci. 5:98-100.

[7] Alonso-Sande M., D. Teijeiro-Osorio. C. Remuñán-López. M.J. Alonso. 2009. Glucomannan. a promising polysaccharide for biopharmaceutical purposes. Europ. J. Pharmaceutics and Biopharmaceutics 72: $453-$ 462.

[8] Armi E. S., M. Ridhwan and H. Syahrizal. 2019. Kerusakan tanaman bawang merah (Allium ascalonicum L.) Akibat seranganhama ulat tanah (Agrotis ipsilon) di lahanbawang merah gamponglam rukam kecamatanpeukan badakabupatenaceh besar. BIOnatural 6: 88-99.

[9] Asmara T. 2019. Serangan Hama Uret Makin Merajalela (An attack of white grub is devastating): https://timlo.net/baca/20537/ serangan-hama-uret-makin-merajalela/ (accessed 10-07-20).

[10] Begna S. H. and D. J. Fielding. 2003. Damage potential of grasshoppers (orthoptera: acrididae) on early growth stages of small-grains and canola under subarctic conditions. J. Econ. Entomol. 96(4): 1193-1200.

[11] Carlos A., R. Vasques C. A. R., S. Rossetto, G. Halmenschlager, R. Linden, E. Heckler, M. S. P. Fernandez and J. L. L. Alonso. 2008. Evaluation of the pharmaco therapeutic efficacy of garcinia cambogia plus Amorphophallus konjac for the treatment of obesity. Phytother. Res. 22: 1135-1140. 
[12] Faizin M., Nadrawati and E. Turmudi. 2019. Tingkat serangan hama penggerek polong, Maruca testulalis Geyer (Lepidoptera: Pyralidae)) pada delapan varietas kacang hijau (Vigna radiata L.) dan pengaruhnya terhadap hasil. JIPI. 21: 55-61.

[13] Fernandes F. L., J. F. S. Diniz, P R. Silva and E. Mosca. 2013. Damage of Agrotis ipsilon (Lepidoptera: Noctuidae)on Coffea arabica in Brazil. Revista Colombiana de Entomología 39: 49-50.

[14] Foster M. A. and M. J. Gaylor. 1987. Black cutworm, Agrotis ipsilon (Lepidoptera: Noctuidae), damage to No-till cotton in relation to larval and plant age. Environmental Entomology, 16: 743-746.

[15] Gesha. 2019. Umbi Porang Laku di Vietnam Rp 708.45 Juta (Corms of porang was sold for Rp 708.45 million in Vietnam). https://tabloidsinartani.com/ detail/industri-perdagangan/olahan-pasar/8462-UmbiPorang-Laku-di-Vietnam-Rp-70845-Juta (Accessed 10-10-19).

[16] Gulluoglu L., H. Arioglu and C. Kurt. 2010. Field evaluation of soybean cultivars for resistance to whitefly (Bemisia tabaci Genn.) infestations. African Journal of Agricultural Research 5: 555-560.

[17] Handayani D. Y. 2019. Ekspor Porang di Jatim Meningkat Dua Tahun Terakhir (Porang export from East Java increased in the last two years). https://kelanakota. suarasurabaya.net/news/2019/223445-EksporPorang-di-Jatim-Meningkat-Dua-Tahun-Terakhir (Accessed 10-10-19:)Ginting E., R. Yulifianti, adn M. Jusuf. 2014. Ubijalar sebagai bahan diversifikasi pangan lokal (sweet potatoes as ingredients of local food diversification). Pangan 23: 194-207.

[18] Hann P., E.-M. Grünbacher, C. Trska, and B. Kromp. 2008. Effects of climate change on the dispersion of white grub damages in the Austrian grassland. 1st Scientific Conference within the framework of the 8th European Summer Academy on Organic Farming, Lednice na Moravě, Czech Republic, September 3-5, 2008. 4p.

[19] Halder B., S. Sultana, T. Akterand and S. Begum. 2018. Life cycle, feeding behavior and nature of damage of sweet potato leaf moth, Agrius cingulata (fabricius) and Agrius convolvuli (linnaeus) (lepidoptera: sphingidae). Dhaka Univ. J. Bol. Sci. 27: 125-134.

[20] Hardoko, L. Hendarto, and T. M. Siregar. 2010. Pemanfaatan ubi jalar ungu (ipomoea batatasl. Poir) sebagai pengganti sebagian tepung terigu dan sumber antioksidan pada roti tawar (Purple Sweet Potato (Ipomoea batatas L. Poir) as a Partial Subtitute of Wheat flour and Source of Antioxidant on Plain Bread). J. Teknol. dan Industri Pangan XXI: 25-32.

[21] Hasyim, A, W. Setiawati, H. Jayanti dan E. H. Krestini. 2014. Repelensi minyak atsiri tehadap hama gudang bawang Ephestia cautella (Walker) (Lapidoptera: Pyrallidae) di Laboratorium [repellency of essential oils against of shallot stored insect Ephestia cautella (Walker) (Lepidoptera : Pyrallidae) Under Laboratory Condition]. J. Hort. 24: 336-345.

[22] Igyuve,T.M., G.O.S. Ojo,., M.S.Ugbaa and A.E. Ochigbo 2018. Fall army worm (Spodoptera frugiperda); it's biology, impact and control on maize production in nigeria. Nigerian. J. Crop Sci. 5: 70-79.

[23] Jagatheesh K., V. Arumugam, N. Elangovan and P. P. Kumar. 2010. Evaluation of the anti-tumor and antioxidant activity of Amorphophallus paeonifolius on dmba induced mammary carcinoma. Internat. J. Chem. Pharmaceutic. Sci. 1: 40-50.

[24] Kasno A., Suharsono and Trustinah. 2015. Respons genotipe kacang tanah terhadap hama kutu kebul (Response of groundnut genotypes to whitefly). Buletin Palawija 13: 64-73. 
[25] Leatemia J. A. and R. Y. Rumthe. 2011. Studi kerusakan akibat serangan hama pada tanaman pangan di kecamatan bula, kabupaten seram bagian timur, propinsi maluku. Jurnal Agroforestri VI: 52-56.

[26] Lolodatu Y., W. N. Jati and F. Zahida. 2019. Pemanfaatan ekstrak daun tembelekan dan daun pepaya sebagai pengendali ulat grayak (Spodoptera litura F.) pada tanaman cabai merah (Capsicum annum L.) (utilization of extract tembelekan leaf and pepaya leaf for pest control armyworms (Spodoptera litura f.) in chili plant (Capsicum annum L.)). Biota 4: 70-78.

[27] Lu S., M. Chen, J. Li, Y. Shi1, Q. Gu and F. Yan. 2019. Changes inBemisia tabacifeedingbehaviors caused directly and indirectly bycucurbit chlorotic yellows virus. Virology Journal 16: 1-14.

[28] Kaya K., F. Cancengiz, M. E. Çalişkan and S. Çalişkan. 2016. The lepidopteran pests of sweet potato: first record of Helcystogramma triannulella (Herrich-Schäffer)(Lepidoptera:Gelechiidae) with population development and natural enemies in Turkey. Türk. Entomol. Derg. 40:149-156.

[29] Maghfiroh A. and D.K. Binawati. 2012. Pengendalian hama ulat tanah (Agrotis ipsilon) dan ulat grayak (Spodoptera exiqua) pada tanaman bawang prei (Allium porrum) dengan bioinsektisida ekstrak daun kersen (Muntingia calabura). Stigma 06: 23-26.

[30] Mamahit J. M. E. and J. Manueke. 2016. Pengendalian hama terpadu tanaman hias di desa Kakaskasen kota Tomohon (jenis-jenis hama pada tanaman krisan di desa Kakaskasen kota Tomohon). Jurnal LPPM Bidang Sains dan Teknologi 3: 81-94.

[31] Mane P. B. and P. B. Mohite. 2014. Efficacy of newer molecules of insecticides against whitegrub in sugarcane. Asian Journal of Bio Science 9: 173-177.

[32] Mani M., C. Shivaraju and A. N. Shylesha. 2012. Paracoccus marginatus, aninvasive mealybug of papaya and its biological control -An overview. Journal of Biological Control 26: 201-216.

[33] Marwoto dan A. Inayati. 2011. Kutu Kebul: Hama Kedelai yangPengendaliannya Kurang Mendapat Perhatian. Iptek Tanaman Pangan 6. 87-98.

[34] Marwoto, Sri Hardaningsih Abdullah Taufiq. 2017. Hama dan Penyakit Tanaman Kedelai: Identifikasi dan Pengendaliannya. Pusat Penelitian dan Pengembangan Tanaman Pangan, Badan Penelitian dan Pengembangan Pertanian. 64p.

[35] Mohammadali M. T, A. A. Alyousuf, H. A. Baqir and A. A. Kadhim. 2019. Evaluation of the efficacy of different Neocontinoid insecticides against cotton whitefly, Bemisia tabaci (Hemiptera : Aleyrodidae) on eggplant under greenhouse condition. Earth and Environmental Science 388: 1-6.

[36] Mir Kabir M.M., M. A. Hossain, T. Farhat, S. Yasmin and N. Md. F. Rahman. 2014. Effects of different botanicals and chemicals on the incidence of sucking insect pests and their impact on mosaic disease of mungbean. Int. J. Innov. Res. \& Dev. 3: 62-68.

[37] Misaka B. C., E. N. Wosula, P. W. Marchelo-d'Ragga, T. Hvoslef-Eide and J. P. Legg. 2020. Genetic diversity of Bemisia tabaci (Gennadius)(Hemiptera: Aleyrodidae) colonizing sweet potato and cassava in South Sudan. Insects 11: 1-15.

[38] Murgianto F. and Purnama Hidayat. 2017. Whitefly infestation and economic comparison of two different pest control methods on soybean production. J. Agro Sci. 5: 110-115.

[39] Narendra A. A.Gde A., T. A. Phabiola And K. A Yuliadhi. 2017. Hubungan antara populasi kutu kebul (Bemisia tabaci) (Gennadius) ( Hemiptera:Aleyrodidae) dengan insiden penyakit kuning pada tanaman 
tomat (Solanum Lycopersicum Mill.) di Dusun Marga Tengah, Desa Kerta, Kecamatan Payangan, Bali (The relationship between population of whiteflies (Bemisia tabaci)(Genemadius) (Hemiptera:Aleyrodidae) with incident of yellow diseaseon tomato plant (Solanum lycopersicumMill.) in Dusun Marga Tengah, Kerta Village, PayanganDistrict, Bali). Agroekoteknologi Tropika 6: 339-348.

[40] Nurrohman E., S. Zubaidah and H. Kuswantoro. 2019. Agronomical performance of soybean genotypes infected by Cowpea Mild Mottle Virus in various level of nitrogen. Biodiversitas 20: 1255-1263.

[41] Oliveira C. M., A.M. Auad, S.M. Mendes, M.R. Frizzas. 2014. Crop losses and the economic impact of insect pests on Brazilian agriculture. Crop Protection 56: 50-54.

[42] Oyewo E. A. and B. O. Amo. 2018. Assessment of damage caused by Ephestia cautella (Walker) to stored cocoa beans. Ghana Jnl Agric. Sci. 52: 25-31.

[43] Pioneer Co. 2018. Hama Uret Serang Tanaman Jagung, Petani di Tuban Terancam Gagal Panen, https://www.pioneer.com/web/site/indonesia/Hama-Uret-Serang-Tanaman-Jagung-Petani-di-TubanTerancam-Gagal-Panen. (Accessed 10-07-2020).

[44] Pratiwi T., Karmanah dan R. Gusmarianti. 2012. Inventarisasi hama dan penyakit tanamanjati unggul nusantara di kebun percobaan cogrek bogor. Jurnal Sains Natural Universitas Nusa Bangsa. 2: 123-133.

[45] Purnama Hidayat P., H. A. Kurniawan, L. Afifah and H. Triwidodo. 2017. Siklus hidup dan statistik demografi kutu kebul Bemisia tabaci (Gennadius) (Hemiptera: Aleyrodidae) biotipe B dan non-B pada tanaman cabai (Capsicum annuum L.)( Life cycle and life table of the B and non-B biotypes of the whitefly Bemisia tabaci (Gennadius) (Hemiptera: Aleyrodidae) on chili pepper (Capsicum annuum L.)). Jurnal Entomologi Indonesia. 14 No. 3, 143-151.

[46] Rahmana A. 2016. Serangan hama ulat jati hantui petani Pamekasan (Teak plantation in Pamekasan was severely attcked larvae of teak insect). https://www.timesindonesia. co.id/read/news/113364/seranganhama-ulat-jati-hantui-petani-pamekasan (accessed 20-07-2020).

[47] Rebek E. and D. Hillock. 2015. Home Vegetable Garden Insect Pest Control. Oklahoma Cooperative Extension Service. Division of Agricultural Sciences and Natural Resources • Oklahoma State University. $8 p$.

[48] Rosary E. D . 2020. Hama Ulat Grayak Serang Ribuan Hektar Lahan Pertanian di Flores. Apa Solusinya? (Army worm badly attacked thousands of hectars of agricultural crops, how to solve it?)(https://www.mongabay.co.id/2020/02/03/hama-ulat-grayak-serang-ribuan-hektar-lahan-pertanian-diflores-apa-solusinya/) (Accessed 16-07-2020).

[49] Saleh N. and Y. Widodo. 2007. Profil dan peluang pengembangan ubi kayu di Indonesia (Cassava profile and its development in Indonesia). Bul. Palawija 14: 69-78.

[50] Saleh N., S. W. Indiati and Y. Widodo. 2015. Hama, penyakit, dan gulma pada tanaman ubi jalar: identifikasi dan pengendaliannya. Pusat Penelitian dan Pengembangan Tanaman Pangan, Badan Penelitian dan Pengembangan Pertanian. 78p.

[51] Setiawati W., A. Hudayya and H. Jayanti. 2014. Distribusi dan kelimpahan populasi orong-orong (Gryllotalpa hirsuta Burmeister), uret (Phyllophaga javana Brenske.), dan ulat tanah (Agrotis ipsilon Hufnagel.) di sentra produksi kentang di Jawa Barat dan Jawa Tengah (Distribution and abundance of the population of mole-cricket (Gryllotalpa hirsuta Burmeister), white grubs (Phyllophaga javana Brenske), 
and black cutworm (Agrotis ipsilon Hufnagel) In potato central production areas in West Java and Central Java). J. Hort. 24:65-75.

[52] Sirisena U.G.A.I., G.W. Watson1, K.S. Hemachandra and H.N.P. Wijayagunasekara. 2013. Mealybugs (Hemiptera: Pseudococcidae) species on economically important fruit crops in Sri Lanka. Tropical Agricultural Research 25: $69-82$.

[53] Soedarjo M. 2015. Postdoctoral research report: Acquisition of the Technique to Analysis of Foods Function toward Human Health Function and Analysis of these Functions in Indonesian Indigenous Tuber Crops, As a result of mutually beneficial collaboration between. Indonesian Agency for Agricultural Research And Development And Kyushu University, Fukuoka, Japan. Indonesian Agency For Agricultural Research And Development. 38p.

[54] Soedarjo M., Y. Baliadi, F. Djufry. 2020. Growth response of porang (Amorphophallus muelleri Blume) grown with different sizes of bulbils on saline soil. International Journal of Research Studies in Agricultural Sciences (IJRSAS) 6: 8-16.

[55] Sugara H. 2020. Kementan dorong madiun kembangkan tanaman porang untuk ekspor (The Indonesian Ministery of Agriculture recommend Madiun regency for porang development). https://monitor.co.id/2020/01/24/kementan-dorong-madiun-kembangkan-tanaman-porang-untuk-ekspor /(Accessed 10-10-19).

[56] Tengkano W. and Suharsono. 2005. Ulat grayak Spodoptera litura Fabricius (Lepidoptera: Noctuidae) pada tanaman kedelai dan pengendaliannya. Bul. Palawija 10: 43-52.

[57] Teshita A. and A. Gashaw. 2014. Corn-root boring white grub and its management, the case of Ethiopia. African J. Basic \& Appl. Sci. 6: 50-56.

[58] Yeh S-L., M-S. Lin and H-L. Chen. 2007 . Inhibitory Effects of a Soluble Dietary Fiber from Amorphophallus konjac on Cytotoxicity and DNA Damage Induced by Fecal Water in Caco-2 Cells. Planta Med. 73: 1384-1388.

[59] Yoshida M., C. A. Vanstone, W. D. Parsons, J. Zawistowski and P. J. H. Jones. 2006. Effect of plant sterols and glucomannan on lipids in individuals with and without type II diabetes. Europ. J. Clinic. Nutrit. 60: 529-537.

[60] Zuraida N. and Y. Supriati. 2001. Usahatani ubi jalar sebagai bahan pangan alternatif dan diversifikasi sumber karbohidrat. Buletin AgroBio 4:13-23.

Citation: Muchdar Soedarjo., " The Field Observed Insects would Challenge The Expansion of Porang (Amorphophallus Muellery Blume) Cultivation in Indonesia" International Journal of Research Studies in Agricultural Sciences (IJRSAS), 2020; 6(12), pp. 12-20, 40-52 https://doi.org/10.20431/2454-6224.0612005

Copyright: (0) 2020 Authors. This is an open-access article distributed under the terms of the Creative Commons Attribution License, which permits unrestricted use, distribution, and reproduction in any medium, provided the original author and source are credited. 